\title{
Penanda DNA: Uji Halal pada Makanan Olahan Daging Menggunakan Primer Multiplex PCR (Polymerase Chain Reaction)
}

\section{(DNA Markers: Halal Test on Processed Meat using Primer Multiplex PCR (Polymerase Chain Reaction)}

\author{
Hanina Dzikrina, Diah Puspita Sari, Nurul Faridah, Salsabila Shafa Saidah, Salma Annisa Nur \\ Alifah, Diah Kusumawaty* \\ Program Studi Biologi, Departemen Pendidikan Biologi FPMIPA \\ Universitas Pendidikan Indonesia, Bandung 40154 \\ *Corresponding author: diah.kusumawaty@upi.edu \\ (Article History: Received Oct 18, 2021; Revised Jan 20, 2022; Accepted Feb 2, 2022)
}

\begin{abstract}
ABSTRAK
Multiplex-PCR merupakan metode yang saat ini sedang populer untuk digunakan karena dapat melakukan pendeteksian lebih dari satu spesies dalam satu tabung, sehingga hasil yang diperoleh lebih cepat, efisien, dan murah dibanding metode PCR biasa. Penelitian ini bertujuan untuk merancang penanda genetik multipleks-PCR untuk deteksi adanya organisme sapi/tikus/ayam/babi pada makanan olahan. Metode yang digunakan terdiri dari dua tahap, yaitu secara in silico dan in vitro. Primer dirancang dengan menggunakan gen sitokrom mitokondria yang didapat dari GeneBank NCBI. Setelah dilakukan alignment, fragmen DNA yang terpilih dijadikan sebagai target sekuen untuk desain primer. Seтиa sikuen pasangan primer di-alignment pada Oli2go primer pooler untuk melihat kemungkinan adanya cross reaction. Hasil dari penelitian ini yaitu primer tikus dan sapi dirancang dengan menggunakan gen COX1, primer babi menggunakan gen KEF22_r01, dan primer ayam menggunakan gen ND6 menghasilkan amplikon dengan ukuran berturut-turut 622 pb, 552 pb, 588 pb dan 272 pb. Namun, amplikon yang dihasilkan dari primer penanda babi, sapi dan tikus sulit dibedakan saat dielektroforesis dalam sumur gel agaros $2 \%$ yang sama. Sedangkan amplikon dari pasangan primer penanda ayam dapat terbedakan saat dielektroforesis baik bersama babi/sapi/tikus. Kesimpulan dari penelitian ini adalah hasil rancangan primer penanda telah dapat digunakan secara bersama jika perbedaan ukuran amplikon $>200 \mathrm{pb}$.
\end{abstract}

Kata kunci: Multiplex PCR; Penanda DNA; Uji halal daging.

\begin{abstract}
Multiplex-PCR (mPCR) is a technique that is gaining popularity due to its ability to detect multiple species in a single tube, resulting in faster results with more efficient and cost-effective resources than the conventional PCR method. This study aimed to design mPCR genetic markers for the detection of bovine/rat/chicken/pork organisms in processed foods. The procedure was divided into two stages: in silico and in vitro. The primers were designed based on mitochondrial cytochrome genes obtained from the NCBI GeneBank. Following alignment, the selected DNA fragments were used as the target sequence for the primer design. The sequences of all primer pairs were aligned on the Oli2go primary pooler to determine whether there was a possibility of cross reaction. The results of this study indicated that primers designed for the COXI gene in rats and bovine, the KEF22 r01 gene in pork, and the ND6 gene in chicken produced amplicons with sizes of $622 \mathrm{bp}$, $552 \mathrm{bp}, 588 \mathrm{bp}$, and $272 \mathrm{bp}$, respectively. However, the amplicons generated from pork, bovine and mouse marker primers were difficult to distinguish when electrophoresed in the same 2\% agarose gel. Meanwhile, the amplicons of the primer markers of chickens can be distinguished when electrophoresed with pork/cows/rat. The study concludes that the designed primer pairs can be used together in MPCR if the difference in amplicon size is greater than $200 \mathrm{bp}$.
\end{abstract}

Key words: Multiplex PCR; DNA markers; Halal meat test. 


\section{PENDAHULUAN}

Barang dan atau jasa yang terkait dengan makanan, minuman, obat, kosmetik, produk kimiawi, produk biologi, produk rekayasa genetik, serta barang gunaan yang dipakai dan dimanfaatkan oleh masyarakat khususnya muslim, yang masuk, beredar, dan diperdagangkan di Indonesia haruslah berlabel halal. Hal ini dijamin oleh UU RI No. 33 Tahun 2014 tentang Jaminan Produk Halal yang tertuang dalam pasal 4 (Rachmawati et al. 2018). Produk halal adalah produk yang sesuai dengan syariah, yaitu tidak melibatkan penggunaan bahan yang haram dan tidak berbahaya atau merugikan (Omar et al. 2012).

Produk olahan daging di Indonesia seperti bakso, nugget, sosis, dan abon diterima dengan baik oleh konsumen karena rasanya yang telah mengalami modifikasi yaitu lebih menarik dengan citarasa yang lebih disukai (Sembor dan Kowel, 2018). Namun, produk pangan yang dibuat dengan campuran daging sangat sulit dibedakan dengan mata telanjang, karena seringkali daging tersebut sudah dihancurkan dan dicampur dengan berbagai bahan lain (Priyanka 2017). Permasalahan tersebut tentu meresahkan masyarakat mengingat sebagian besar masyarakat Indonesia adalah umat muslim yang hanya mengkonsumsi makanan yang halal (Larasati 2018). Oleh karena itu, diperlukan suatu metode yang cepat dan efisien untuk mendeteksi jenis daging yang digunakan dalam produk olahan daging, sehingga dapat menjamin kehalalan daging yang digunakan.

\section{Multiplex PCR (m-PCR)} merupakan metode yang saat ini sedang populer untuk digunakan karena dapat melakukan pendeteksian yang lebih cepat, efisien, dan murah dibanding metode PCR biasa
(Prusakova et al. 2018). Alikord et al. (2016) telah menemukan metode yang cepat dan sensitif untuk mendeteksi jenis daging pada produk daging halal di Turki dengan Multiplex PCR. Biasanya masyarakat mengkonsumsi produk olahan daging yang berbahan dasar daging sapi, ayam, ikan dan babi, sehingga perlu dicari metode untuk mendeteksi jenis daging pada produk olahan daging yang beredar di Indonesia.

Gen COX1 merupakan gen yang mengkode protein Cytochrome c oxidase subunit 1 di mitokondria dan berperan dalam rantai transpor elektron (UniProt, t.t.). Sedangkan gen ND6 (disimbolkan juga sebagai MTND6) pada ayam merupakan gen yang mengkode protein NADH-ubiquinone oxidoreductase chain 6 , berlokasi di mitokondria, merupakan subunit inti dari rantai pernapasan membran mitokondria NADH dehidrogenase (UniProt, t.t.).

Tujuan utama penelitian ini adalah mendapatkan penanda genetik multipleks untuk deteksi adanya organisme sapi/tikus/ayam/babi pada makanan olahan serta mengembangkan desain dan optimasi multiplex untuk mendeteksi secara cepat kehalalan jenis daging yang digunakan dalam produk olahan daging menggunakan primer multipleks gen cyt, CO1, COX1, KEF22_r01, dan ND6 pada daging sapi, ayam, babi, dan tikus dengan metode Multiplex-PCR.

\section{METODE}

Metode penelitian yang digunakan adalah metode secara in silico dan in vitro. Alat dan bahan yang digunakan dalam penelitian ini yaitu, pisau, mortar dan alu, aluminium foil, autoklaf, gelas beker, gelas ukur, kit elektroforesis gel, kulkas, mesin elektroforesis, mini PCR, mikropipet, 
pipet, Oli2go website, sentrifuge, spatula, spektrofotometer, timbangan analitik, tips, tube, tabung eppendorf, vortex, UV Transilluminator, NCBI Primer-BLAST, daging mentah segar (babi, ayam, sapi, tikus), sosis, nugget, bakso, kit isolasi DNA, air destilat (aquades), TAE, GoTaq@ Green Master Mix 2X, air deion, loading dye, DNA ladder, data sekuens multiplex PCR primer forward dan reverse, pewarna biru bromtimol, agarosa, larutan buffer (TBE), pewarna ethidium bromide, primer forward, primer reverse, enzim Taq polimerase.

\section{Metode Protokol PCR dan mPCR secara Studi Pustaka}

Single-PCR dilakukan dengan cara menguji primer satu per satu pada tiap sampel. Optimasi two tube-mPCR dilakukan dengan cara membagi dua grup primer yang digunakan berdasarkan suhu annealing dan panjang fragmen DNA. Primer-primer ini kemudian dimasukkan ke dalam tube PCR 1 dan tube PCR 2. Tiap terdiri atas 12,5 $\mu$ l GoTaq@ Green Master Mix 2X, 10,5 $\mu \mathrm{l}$ DNA template, dan $2 \mu$ campuran primer lalu dilakukan replikasi DNA menggunakan mesin PCR (Xiong et al. 2019).

\section{Metode secara In Silico \\ Perancangan Desain Primer Gen Penanda Halal}

Primer yang digunakan adalah gen sitokrom mitokondria yang didapat dari GeneBank NCBI. Setelah dilakukan alignment, fragmen DNA yang terpilih dijadikan sebagai target sekuen untuk desain primer. Semua sekuen pasang primer di-alignment pada Oli2go primer pooler untuk melihat kemungkinan adanya cross reaction (Xiong et al. 2019).
Perancangan Multiplex PCR secara In Silico

Pada perancangan primer multipleks, hal yang perlu diperhatikan adalah adanya dimer dan overlaps antar primer yang akan digunakan (Henegariu et al. 1997). Kedua hal tersebut dapat menimbulkan permasalahan pada saat melakukan mPCR, seperti timbulnya pita DNA non specific pada hasil amplifikasi. Maka, untuk memperkecil kemungkinan terjadinya dimer dan overlaps antar primer, dilakukan pengujian primer pustaka yang akan digunakan pada uji mPCR. Pengujian ini dilakukan secara in silico pada protokol mPCR menggunakan software Primer Pooler oleh Silas et al. (2017). Program kerja pada software ini menggunakan protokol standar PrimerPooler (http://ssb22.user.srcf.net/pooler/).

\section{Metode secara In Vitro \\ Metode Isolasi dan Ekstraksi Sampel DNA}

Isolasi dan ekstraksi DNA pada penelitian ini berasal dari sampel daging segar dan produk olahan daging dengan menggunakan kit isolasi DNA. Sampel DNA sebanyak 0,01 gr dimasukkan ke dalam tabung eppendorf $1,5 \mathrm{~mL}$ ditambahkan 600 $\mu \mathrm{L}$ buffer nuclei lysis, dan diinkubasi selama 30 menit pada suhu $65^{\circ} \mathrm{C} .3 \mu \mathrm{L}$ Rnase dimasukan pada tube selama 25 menit, lalu diinkubasi selama 30 menit pada suhu $30^{\circ} \mathrm{C}$ serta diamkan di suhu ruangan selama 5 menit. 200 $\mu \mathrm{L}$ protein precipitation ditambahkan dan vortex dengan kecepatan tinggi selama 20 detik, lalu sampel disimpan di atas es selama 5 menit. Selanjutnya disentrifugasi selama 4 menit dengan kecepatan 13,000-16,000×g. Supernatan diambil dan dipindahkan ke dalam tabung eppendorf $1,5 \mathrm{~mL}$ yang baru, kemudian ditambahkan 600 
$\mu \mathrm{L}$ isopropanol dan pipeting. Sentrifugasi selama 1 menit, dan DNA akan terlihat pada pellet. Supernatan dibuang, kemudian ditambahkan 600 $\mu \mathrm{L}$ etanol $70 \%$, dan dilakukan sentrifugasi selama 1 menit. Etanol dibuang, dan didiamkan selama 15 menit dengan posisi tutup tabung terbuka. Ditambahkan $100 \mu \mathrm{L}$ DNA rehydration dan diinkubasi pada suhu $4^{\circ} \mathrm{C}$ selama semalam atau pada suhu $65^{\circ} \mathrm{C}$ selama 1 jam.

\section{Metode Optimasi Protokol dan Amplifikasi PCR}

Optimasi two tube-mPCR dilakukan dengan cara membagi dua grup primer yang digunakan berdasarkan suhu annealing dan panjang fragmen DNA untuk menentukan suhu yang optimal yang akan digunakan pada amplifikasi. Amplifikasi segmen gen cyt, CO1, COX1, KEF22_r01, dan ND6 dilakukan dengan metode multipleks PCR. Sampel DNA sebanyak $2 \mu \mathrm{L}$ dimasukkan ke dalam tabung PCR 0,2 $\mathrm{mL}$, komponen PCR yang ditambahkan terdiri dari $1 \mu \mathrm{L}$ primer forward dan reverse 5 pmol, 12,5 $\mu \mathrm{L}$ enzim GoTaq@ Green Master Mix 2X, digenapkan menggunakan air deion sampai $25 \mu \mathrm{L}$. Proses amplifikasi dilakukan pada thermal cycler GeneAmp ${ }^{\circledR}$ PCR System (Applied Biosystems TM) dengan suhu $95^{\circ} \mathrm{C}$ selama 30 detik, 35 siklus terdiri dari denaturasi $95^{\circ} \mathrm{C}$ selama 30 detik, anealing $55^{\circ} \mathrm{C}$ selama 45 detik, extension $72^{\circ} \mathrm{C}$ selama 36 detik dan final extension $72^{\circ} \mathrm{C}$ selama 5 menit. Setelah proses selesai, tabung diambil dan disimpan pada suhu kamar atau pada suhu $4^{\circ} \mathrm{C}$, selanjutnya akan dianalisis.

\section{Metode Elektroforesis dan Visualisasi Hasil PCR}

Produk PCR divisualisasikan dalam gel agarose 3\% menggunakan teknik elektroforesis. Gel dibuat dari 0,6 gram agarosa dan $20 \mathrm{ml}$ larutan TBE 1x. Larutan agarosa dibiarkan agak dingin sambil diaduk dengan alat pengaduk, kemudian ditambahkan pewarna etidium bromida $1 \mu \mathrm{L} .10 \mu \mathrm{L}$ produk PCR dilarutkan dalam $2 \mu \mathrm{L}$ loading dye. Elektroforesis dilakukan selama 30 menit pada tegangan konstan 100 volt atau hingga pewarna biru bromtimol mencapai dasar gel. Setelah elektroforesis selesai, gel diambil untuk fotografi UV.

\section{HASIL DAN PEMBAHASAN \\ Hasil Desain Primer Spesifik Gen Penanda Halal secara In Silico}

Desain primer spesifik dilakukan secara in-silico menggunakan data whole genome mitochondrion dari GenBank NCBI dan software PrimerPooler. Berdasarkan hasil primer dari NCBI, didapatkan primer spesifik ayam, babi, sapi, dan tikus yang dapat dilihat pada Tabel 1 .

Primer spesifik yang sudah didapatkan kemudian diuji menggunakan software PrimerPooler untuk simulasi optimasi secara in silico primer yang didesain spesifik pada daging ayam, babi, sapi, dan tikus. Hasil yang berhasil akan ditandai dengan tulisan all amplicon were found atau tidak terjadi cross dimer maupun self dimer. Selanjutnya, urutan primer multiplex-PCR spesifik yang berhasil, dipesan ke MacroGen. 
Tabel 1. Primer Spesifik Ayam, Babi, Sapi, dan Tikus

\begin{tabular}{|c|c|c|c|}
\hline Species & Gene & Sekuens & $\begin{array}{c}\text { Amplicon } \\
\text { Length }\end{array}$ \\
\hline Tikus & COX1 & 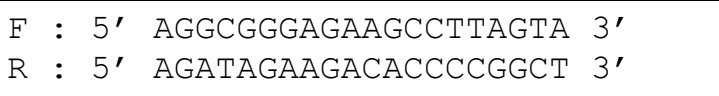 & 622 bp \\
\hline Sapi & COX1 & 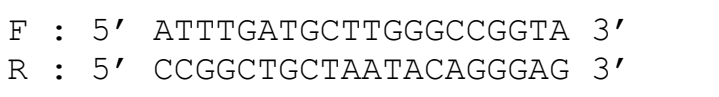 & 552 bp \\
\hline Babi & KEF22_r01 & $\begin{array}{l}\mathrm{F}: 5^{\prime} \text { ATGGGCTACATTTtCtACATGAGT } 3^{\prime} \\
\mathrm{R}: 5^{\prime} \text { AACTGCTCATGGGTAGCTCG } 3^{\prime}\end{array}$ & 588 bp \\
\hline Ayam & ND6 & $\begin{array}{lll}\mathrm{F}: & 5^{\prime} \text { AAATCAACGAGCCCTCCCAG } & 3^{\prime} \\
\mathrm{R}: & : & 5^{\prime} \\
\text { GCGTCTAATCCTTCGCCGTA } & 3^{\prime}\end{array}$ & 272 bp \\
\hline
\end{tabular}

Simulasi Hasil PCR dan Multiplex PCR secara In Silico

Hasil PCR dan multiplex PCR secara in silico ditunjukkan dengan adanya gen target yang teramplifikasi, posisi pita hasil elektroforesis gel menunjukan ukuran dari gen tersebut yang disamakan posisinya dengan marker (Gambar 1).



Pada (Gambar 1) dapat dilihat contoh hasil PCR pada sampel sapi, babi, tikus, dan ayam dalam 1 sumur hanya terdiri dari 1 pita, sedangkan pada multiplex-PCR dalam 1 sumur terdiri 4 pita sekaligus. Hasil tersebut menunjukkan kelebihan dari mPCR yaitu karena dapat mengamplifikasi dua atau lebih sekuen target dengan satu kali reaksi PCR sehingga dapat menghemat waktu pengerjaan serta alat dan reagen yang digunakan lebih murah (Edwards dan Gibbs 1994).

\section{Hasil Isolasi DNA}

Hasil isolasi DNA ditentukan menggunakan elektroforesis dengan gel agarose 3\%, sampel hasil isolasi DNA daging ayam, babi, sapi, dan tikus dicampur dengan loading dye lalu diuji elektroforesis menggunakan BlueGel. Hasil uji elektroforesis DNA dapat dilihat dari adanya pita yang terbentuk (Gambar 2). Didapatkan bahwa hasil isolasi DNA daging tikus memiliki pita yang tebal sehingga dapat dikatakan bahwa DNA yang terisolasi dari daging tikus cukup banyak. Sedangkan pada daging ayam terlihat adanya pita hanya saja hasilnya kurang bagus karena pita yang terbentuk kurang jelas. Untuk daging babi dan sapi, hasil pitanya tipis sehingga DNA yang terisolasi hanya sedikit sehingga harus dilakukan amplifikasi untuk mereplikasi DNA yang sudah diisolasi sehingga mendapatkan DNA dengan jumlah yang lebih banyak (Gambar 2).

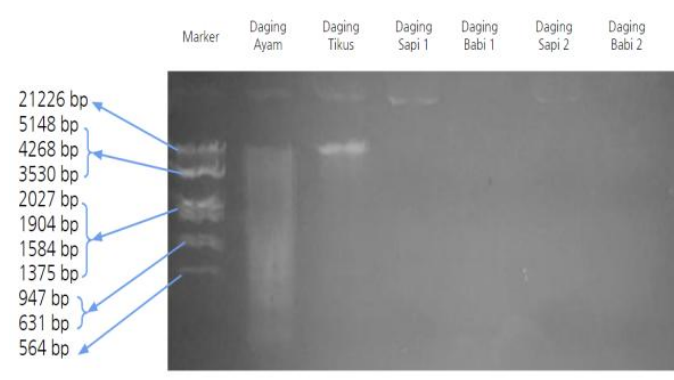

Gambar 2. Hasil Elektroforesis DNA yang sudah diisolasi

\section{Hasil Amplifikasi}

Amplifikasi dilakukan untuk mereplikasi DNA yang sudah diisolasi 
sebelumnya sehingga mendapatkan DNA target dengan jumlah yang banyak dan saat elektroforesis akan terlihat hasil ketebalan pita yang muncul. Hasil isolasi DNA kemudian ditambahkan pewarna DNA, mix enzim, dan primer forward reverse. Setelah itu dimasukkan ke dalam miniPCR dan dilakukan running. Hasil dari miniPCR berupa jumlah DNA yang dapat direplikas.

\section{Hasil Elektroforesis dan Validasi PCR}

PCR digunakan untuk mengamplifikasi DNA yang sudah diisolasi, lalu hasil PCR digunakan untuk melihat apakah hasil dari isolasi DNA berhasil atau tidak menggunakan uji elektroforesis. Hasil elektroforesis akan menunjukkan pita-pita DNA, ketebalan pita akan didasarkan pada berat dan jumlah DNA nya. Berdasarkan hasil elektroforesis, didapatkan bahwa DNA yang diisolasi berhasil ditunjukkan adanya pita berwarna putih (Gambar 3). Namun, beberapa sumur tidak terdapat pita atau terlihat sangat tipis. Hal ini dikarenakan konsentrasi DNA pada daging yang diisolasi kurang dari 14 $\mu \mathrm{g} / \mu \mathrm{l}$, atau jika pada daging olahan, DNA yang terkandung pada makanan olahan ada kontaminan atau tertutupi oleh kandungan protein, karbohidrat, atau lainnya yang terdapat pada makanan olahan tersebut. Menurut Wahyuni et al. (2019) nilai kemurnian di bawah 1,8 menunjukkan bahwa DNA masih terdapat kontaminan berupa protein dan polisakarida.

Selain itu, DNA daging ayam dan sapi memiliki pita yang tebal, sementara pita pada daging babi terlihat tipis dan saat digabung dengan daging sapi tidak terlihat karena didominasi oleh DNA daging sapi. Sehingga perbedaan ukuran DNA target dengan ukuran target $<100 \mathrm{bp}$ sulit dibedakan, namun jika DNA target dengan perbedaan ukuran $>100$ bp lebih mudah dibedakan. Bisa dilihat dari DNA daging sapi dan babi tidak dapat digabungkan karena perbedaan amplikon yang $<100$ bp. Selain itu, pita hasil elektroforesis PCR DNA daging tikus terlihat tipis bahkan tidak ada, hal ini dapat disebabkan karena adanya perbedaan primer atau spesies yang digunakan, akibatnya hasil elektroforesis tidak ada.

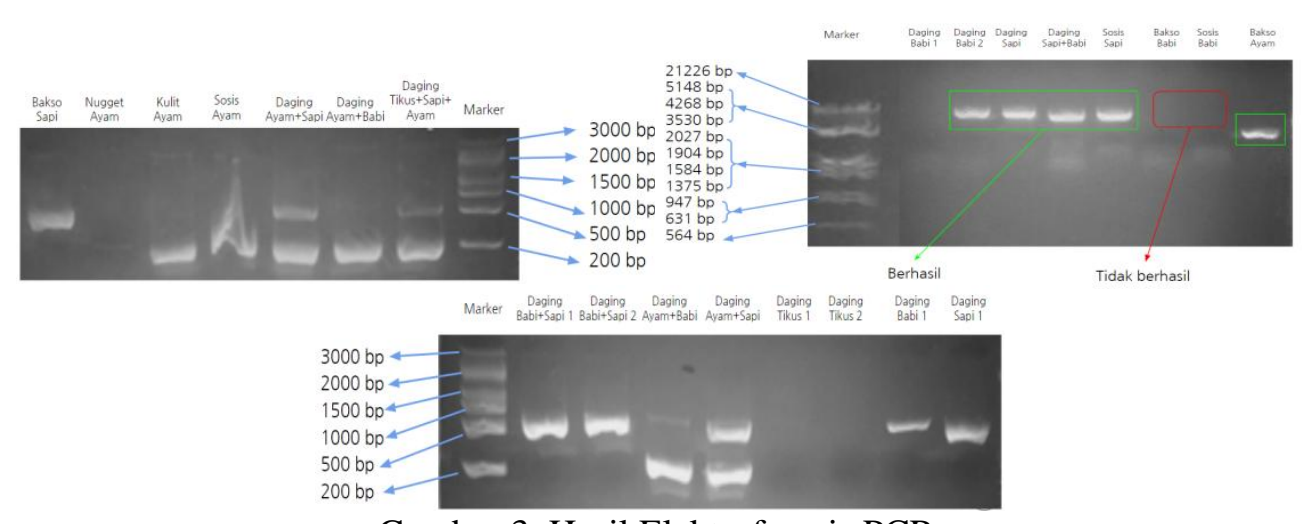

Gambar 3. Hasil Elektroforesis PCR

\section{Hasil Keterkaitan antara Kualitas DNA dengan Keberhasilan PCR}

Penentuan konsentrasi DNA ditentukan menggunakan spektrofotometri UV. Rasio kemurnian DNA kurang dari 1,8 menunjukkan bahwa DNA tidak cukup murni. Sesuai dengan penelitian Fatchiyah et al. (2011), bahwa nilai kemurnian DNA yang baik biasanya berkisar antara 1.8 hingga 2.0. Namun hasil dari penelitian kami nilai kemurnian 
DNA berkisar $1.4-1.7$ berhasil pada proses PCR

Menurut (Sambrook dan Russel, 1989 dalam Ningsih et al. 2016) DNA dikatakan murni apabila mempunyai nilai perbandingan absorbansi $\lambda$ 260/280 nm berkisar 1,8-2,0. Pada kemurnian DNA yang nilainya lebih rendah dari 1,8 menunjukkan sampel DNA terkontaminasi oleh protein, sedangkan kemurnian DNA yang nilainya lebih tinggi dari 2,0 artinya sampel DNA terkontaminasi oleh RNA. Pada perbandingan absorbansi $\lambda$ 260/230 nm DNA murni berkisar antara 2-2,2. Jika nilainya lebih rendah dari 2 maka DNA terkontaminasi oleh karbohidrat, bahan organik, dll.

\section{KESIMPULAN}

Kesimpulan yang kami dapatkan bahwa primer multipleks untuk mendeteksi adanya organisme sapi, babi, ayam, dan tikus dapat teramplifikasi dengan baik, tetapi pada gel agarose, primer yang dapat terpisahkan dengan baik hanya primer ayam karena perbedaan panjang basa yang >100 bp dari primer sapi, babi, maupun tikus.

\section{UCAPAN TERIMA KASIH}

Penelitian ini dibiayai oleh Program Kreativitas Riset Eksakta Mahasiswa 2021 Simbelmawa Kemdikbud.

\section{DAFTAR PUSTAKA}

Alikord M, Keramat J, Kadivar M, Momtaz H, N Eshtiaghi M, \& Homayouni-Rad A (2016) Multiplex-PCR as a rapid and sensitive method for identification of meat species in halal-meat products. Recent patents on food, nutrition \& agriculture. 8(3):175182.

Edwards MC, Gibbs RA (1994) Multiplex PCR: Advantages, Development, and Applications.
Cold Spring Harbor Laboratory 3: 65-75.

Fatchiyah, ELA, Sri W, dan Sri R (2011) Biologi Molekuler Prinsip Dasar Analitis. Penerbit Erlangga. Jakarta.

Henegariu O, Heerema NA, Dlouhy SR, Vance GH, Vogt PH (1997) Multiplex PCR: Critical Parameters and Step-by-Step Protocol. BioTechniques, 23(3): 504-511.

Larasati DUR (2018) Limit of detection (LOD) fragmen DNA pengkode gen Sitokrom B (cyt b) babi (Sus scrofa). Skripsi. UIN Sunan Ampel Surabaya.

Ningsih TY, Wahyono D, Gumilas NSA (2016) Deteksi Gen Litik BRLF1 Epstein-Barr Virus pada Penderita Karsinoma Nasofaring. Majalah Ilmiah Biologi BIOSFERA: A Scientific Journal, 35(1): 29-36.

Omar KM, Mat NKM, Imhemed GA, Ali FMA (2012). The Direct Effects of Halal Product Actual Purchase Antecedents among the International Muslim Consumers. American Journal of Economics, 2(4): 87-92.

Priyanka VA (2017) Deteksi Cemaran Daging Babi pada Produk Sosis Sapi di Kota Yogyakarta dengan Metode Polymerase Chain Reaction. Jurnal Teknobiologi. 116.

Prusakova OV, Glukhova XA, Afanas'eva GV, Trizna YA, Nazarova LF, Beletsky I (2018) A simple and sensitive two-tube multiplex PCR assay for simultaneous detection of ten meat species. Meat science. 3(137):3440.

Rachmawati Y, Rokhim S, Munir M, Agustina E (2018) Deteksi Kontaminan Fragmen Dna Pengkode Cyt B Babi Pada Sampel Softgellcandy Tak Berlabel Halal. 
Indonesia Journal of Halal. 1 (1):25-30.

Sembor SM, Kowel YHS (2018)

Penyuluhan dan Demonstrasi

Pengolahan Bakso dan Nugget

Ayam Petelur Afkir pada

Kelompok WKI GMIM Jemaat

Betlehem Kelurahan Singkil I

Kecamatan Singkil Kota Manado.

Seminar Nasional PERSEPSI III.

Manado. 6-7 September 2018,

Manado, Indonesia. 559-562.

Silas SB, Yun-Wen C, Ming W, Alexandra C, Eguzkine O, MingQing D (2017) PrimerPooler: automated primer pooling to prepare library for targeted sequencing. Biology Methods and Protocols. Oxford University Press. 2(1).
UniProt, Tanpa Tahun. UniProtKB P05503 (COX1_RAT). URL: https://www.uniprot.org/uniprot/P0 5503. Diakses Tanggal 5 Agustus 2021.

Wahyuni S, Maryam S, Aminah (2019) Validasi Metode Analisis Cemaran DNA Babi pada Bakso Sapi Menggunakan Primer Mitokondria D-Loop22 dengan Metode Polymerase Chain Reaction (PCR). Jurnal Farmasi Galenika. Galenika Journal of Pharmacy 5(1): $65-72$.

Xiong J, Huang B, Guo SL, Xu JS, Huang W (2019) A Novel multiplex PCR assay for rapid detection of virulent Aeromonas in cultured eels. Jounal of Applied Microbiology. 127:418-428. 